\title{
Functional Electrical Stimulation dengan Pulsa Biphasic Untuk Membantu Fungsi Ekstremitas Atas Pasien Pasca Stroke
}

\author{
Deny Arifianto*1, Karina Ais Mardika Limassari², Khusnul Ain ${ }^{3}$, \\ Suryani Dyah Astuti ${ }^{3}$ \\ ${ }^{1}$ Departemen Teknik, Fakultas Vokasi, Universitas Airlangga, Surabaya, 60286 \\ ${ }^{2}$ Teknik Biomedis Departemen Fisika Fakultas Sains dan Teknologi Universitas Airlangga \\ Surabaya, 60115 \\ ${ }^{3}$ Departemen Fisika Fakultas Sains dan Teknologi Universitas Airlangga Surabaya, 60115 \\ *1e-mail : deny-a@ vokasi.unair.ac.id \\ 2e-mail : karina@gmail.com \\ 3e-mail : k_ain@fst.unair.ac.id \\ ${ }^{4}$ e-mail : suryanidyah@fst.unair.ac.id
}

\begin{abstract}
Stroke or nerve function disorders caused by disruption of blood flow to the brain that arises suddenly or quickly with symptoms or signs that correspond to the affected area. One of the post-stroke rehabilitation using electrical stimulation, also known as an electro stimulator. This study aims to design Functional electrical stimulation (FES), which aims to stimulate the peripheral nervous system with biphasic pulses. Stimulation for patients with MMT 1 was optimal at a frequency of 22-30 Hz. In post-stroke patients with MMT inclusion characteristics 0-3, a minimum voltage, frequency and pulse width value of $200 \mathrm{Vp}, 22 \mathrm{~Hz}$, and $20 \mathrm{~s}$ is required with a power of 0.00146 Watt. Studies have shown that this electro stimulator device had good accuracy and has high peak voltage values and low effective current. It can be considered because it provides comfort and safety for medical therapy equipment.
\end{abstract}

Keywords: Electro Stimulator, FES, Biphasic pulse spike, health care

Abstrak

Stroke atau Gangguan fungsi saraf yang disebabkan oleh gangguan aliran darah ke otak yang timbul secara mendadak atau secara cepat dengan gejala atau tanda yang sesuai dengan daerah yang terganggu. Salah satu rehabilitasi pasca stroke dengan menggunakan stimulasi listrik yang dikenal juga sebagai elektrostimulator. Penelitian ini bertujuan untuk mendesain Functional electrical stimulation (FES) yang bertujuan untuk merangsang sistem saraf perifer dengan pulsa biphasic. Pemberian stimulasi untuk naracoba pasien dengan MMT 1 mencapai optimal pada frekuensi $22-30 \mathrm{~Hz}$. Pada naracoba pasien pasca stroke dengan karakteristik inklusi MMT 0-3 dibutuhkan nilai tegangan, frekuensi dan lebar pulsa minimal sebesar $200 \mathrm{Vp}, 22 \mathrm{~Hz}$, dan 20 ps dengan daya 0.00146 Watt. Studi yang telah dilakukan menunjukan bahwa alat elektrostimulator yang diwujudkan memiliki akurasi yang baik dan memiliki keuntungan di nilai tegangan puncak yang tinggi dan arus efektif yang rendah, sehingga dapat dipertimbangkan karena memberikan kenyamanan dan keamanan pada peralatan terapi medis.

Kata Kunci:Elektro stimulator, FES, pulsa bifasik

\section{PENDAHULUAN}

Cerebrovascular Disease atau

Stroke (istilah yang tidak tepat ) atau dalam bahasa Indonesia gangguan peredaran darah otak ( GPDO ) adalah gangguan fungsi saraf yang disebabkan oleh gangguan aliran darah ke otak yang timbul secara mendadak atau secara cepat dengan gejala atau tanda yang sesuai dengan daerah yang terganggu. Menurut WHO (2012), diperkirakan setiap tahun di Indonesia terjadi 500.000 penduduk terkena serangan stroke, dan sekitar $25 \%$ atau 125.000 orang meninggal dan sisanya mengalami cacat ringan atau berat. Indonesia merupakan negara dengan jumlah penderita stroke terbesar di Asia, 
(C) (2021) Sekolah Pascasarjana Universitas Airlangga, Indonesia

sehingga perlu pelayanan kesehatan yang memadai.

Mayoritas kecacatan jangka panjang akibat stroke adalah keterbatasan penggunaan lengan. Dilaporkan dari beberapa penelitian $65 \%$ individu stroke tidak dapat menggunakan fungsi ekstremitas atas dalam kehidupan seharihari (Lum et al., 2009). Tingkat kecacatan pasca stroke berbeda tergantung pada klasifikasi jenis stroke yang dialami. Salah satu indikator pengukuran kecacatan stroke terhadap fungsi gerak dapat diukur dengan menggunakan manual muscle testing (MMT) dengan range 0-5 (Conable, 2011). Berdasarkan hal tersebut, pasien stroke saat ini umumnya masih dalam usia yang memiliki produktifitas tinggi sehingga dibutuhkan alat bantu rehabilitasi pasca stroke. Salah satu rehabilitasi pasca stroke dengan menggunakan stimulasi listrik yang dikenal juga sebagai elektrostimulator

Functional electrical stimulation (FES) adalah Electrical Stimulation yang merangsang sistem saraf perifer untuk tujuan memberikan bantuan dinamis dalam kegiatan fungsional, seperti berjalan atau fungsi ekstremitas atas dan juga bertujuan untuk menginduksi kontraksi otot. Implementasi stimulator dapat dijadikan stimulator tanam dan perangkat eksternal. Untuk perangkat eksternal, sinyal merangsang menembus ke saraf target melalui elektroda pada permukaan kulit manusia dengan cara pulsa monofasik atau pulsa bifasik. Huerta et al. (2012). Transfer pulsa monofasik merangsang pembentukan tegangan untuk saraf dalam periode pulsa yang sangat singkat, sehingga memerlukan waktu yang lama dan dapat menyebabkan kelelahan otot.

Berdasarkan kajian Biofisika Unair, di pasaran telah banyak produk elektrostimulator yang tidak menggunakan stabilizer, sehingga apabila intensitas diubah maka frekuensinya juga berubah. Pada kondisi tersebut jelas membahayakan bagi pasien, karena meningat sumber arus PLN yang naik dan turun sehingga besarnya intensitas yang diberikan sangat JBP Vol. 23, No.01, Juni 2021 - Deny Arifianto berpengaruh terhadap efektivitas terapi yang dilakukan.

Huerta et al. (2012) (dalam Tamtrakarn, 2015) menyebutkan bahwa implementasi stimulator dapat dijadikan stimulator tanam dan perangkat eksternal. Untuk perangkat eksternal, sinyal merangsang menembus ke saraf target melalui elektroda pada permukaan kulit manusia dengan cara pulsa monofasik atau pulsa bifasik. Penelitian Philip et al. (1998) dan Simcox et al. (2004) menunjukkan bahwa pola pulsa frekuensi sekitar 20$100 \mathrm{~Hz}$ dengan lebar pulsa dari $25-800 \mu \mathrm{s}$ cukup baik sebagai pola FES. Pada stimulator pulsa yang memungkinkan adalah dengan amplitudo di antara 5mA100mA (McNulty et al., 2009). Sedangkan parameter electrical stimulation menurut Cheng et al. (2004) terkait batas tegangan puncak yang dibutuhkan untuk menghasilkan kontraksi yaitu 20-200Vp.

Dasar yang menjadi acuan pada penelitian ini adalah penelitian yang dilakukan oleh Addawiyyah (2015) yaitu rancang bangun FES untuk membantu fungsi ekstremitas atas penderita stroke dengan menggunakan gelombang monophasic square. Penelitian yang telah dilakukan tersebut mampu memberikan efek positif sesuai dengan tujuan perancangan, namun berdasarkan teori yang ada, gelombang spike diyakini lebih baik atau lebih nyaman digunakan untuk terapi pasien daripada gelombang square. FES yang akan dirancang pada penelitian ini akan lebih difokuskan untuk mengembalikan fungsional ekstremitas atas. Hal tersebut dilakukan karena tujuan perancangan FES ini adalah sebagai alat bantu rehabilitasi pasca stroke yang diharapkan lebih unggul dan mudah dibawa (portable), dengan menggunakan gelombang biphasic spike berbasis Arduino Uno membantu fungsi ektrimitas atas pada penderita pasca stroke.

\subsection{Ekstrimitas Atas}

Ekstrimitas atas merupakan fungsional gerak atas ynag terdiri dari 

pundak, siku, pergelangan tangan dan tangan. Menurut Floyd (2007) gerakan pergelangan tangan dibagi menjadi empat gerakan: fleksi, ekstensi abduksi dan adduksi, seperti pada gambar 2.1 Gerakan yang dipilih adalah gerakan fleksi yang dipengaruhi oleh tiga otot: flexor carpi radialis, flexor carpi ulnaris dan Palmaris longus

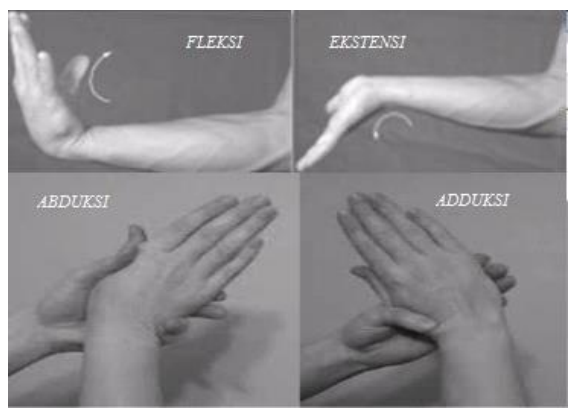

Gambar. 2.1. Gerakan Pergelangan Tangan (Floyd, 2007)

\subsubsection{Potensial Aksi Motor Unit}

Stimulus saraf terbagi menjadi tiga fase: fase istirahat, depolarisasi, dan repolarisasi sebagaimana ditunjukkan pada Gambar 2.2. Potensial membrane istirahat adalah keadaan dimana beda potensial antara didalam dan diluar sel stabil (tidak tereksitasi). Pada keadaan potensial membran istirahat, beda potensial membran dalam dan luar berada pada range nilai $80 \mathrm{mV}$ hingga-90mV. Beda potensial tersebut disebabkan oleh perbedaan konsentrasi ionik antara membran dalam dan luar. Diluar sel, konsentrasi $\mathrm{Na}+$ lebih tinggi, sedangkan didalam sel, konsentrasi K+ lebih tinggi (Lopez, 2012).

Depolarisasi terjadi pada saat beda potensial antara ekstrasel dan intrasel mengalami perubahan.. Aktivasi voltagegated sodium channel terjadi ketika potensial membran menjadi lebih tidak negatif dari keadaaan istirahat yaitu pada saat beda potensial naik menjadi -70 hingga $-50 \mathrm{mV}$. Hal tersebut akan membuka voltage-gated sodium channel dan meningkatkan permeabilitas membran terhadap ion sodium sebesar 500-5000 lipat (Guyton dan Hall, 2006).

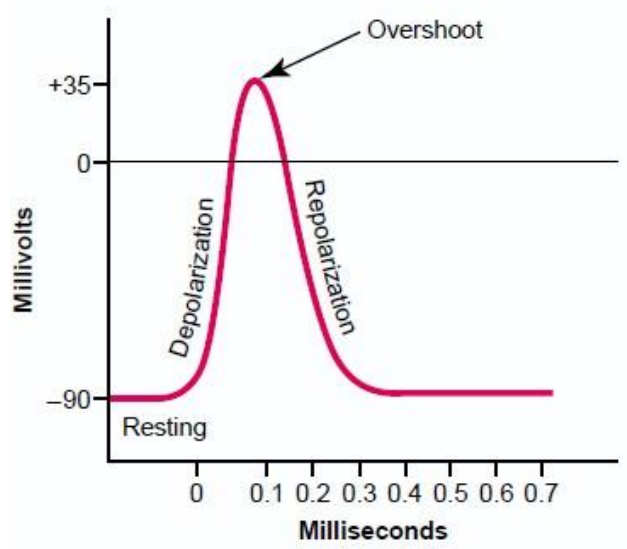

Gambar 2.2 Fase stimulus syaraf

Potensial aksi pada saraf tidak akan terjadi selama beda potensial tidak terdistribusi merata sepanjang membran. Potensial membran yang dibutuhkan untuk mencapai potensial aksi adalah $15-30 \mathrm{mV}$. Repolarisasi adalah kondisi dimana kanal sodium tertutup dan kanal potassium terbuka sehingga ion $\mathrm{K}+$ keluar melintasi membran.

\subsubsection{Gangguan Ekstrimitas Atas pada Penderita Stroke}

Cedera otak, termasuk stroke menghasilkan ketidakseimbangan impuls penghambatan dan rangsang yang mengarah ke gejala neuron motorik atas. Lokasi dan luasnya lesi mengakibatkan gejala dan tingkat keparahan kejang berbeda-beda pada tiap pasien (Ward AB, 2012). Efek fisik setelah stroke diantaranya: kelemahan otot, drop foot, stamina, rasa sakit, dan spasticity.

Kelemahan otot umumnya terjadi pada satu bagian tubuh atau disebut hemiparesis. Hemiparesis disebabkan oleh perubahan fisiologi yang terjadi pada saraf dan otot. perubahan fisiologi yang terjadi diantaranya: penurunan jumlah satuan saraf motor, perubahan pada konduksi saraf tepi, dan perubahan pada morfologi dan sifat mekanik otot (Bourbonnais, 1989).

Spasticity atau kekejangan otot paska stroke terjadi akibat ketidaksinambungan atau disintegrasi antara respon motor dan input sensorik yang mengarah ke eksitasi berlebih dari 
Jurnal Biosains Pascasarjana Vol. 23 (2021) pp

(C) (2021) Sekolah Pascasarjana Universitas Airlangga, Indonesia

sistem saraf pusat. Timbulnya spasticity berkaitan dengan reorganisasi neuronal setelah lesi otak. Hasil reorganisasi neuronal patologis ini dapat meningkatkan aktivitas pada otot dan respon refleks yang berlebihan terhadap stimulasi perifer. Kekakuan otot mengakibatkan penderita pasca stroke mengalami kesulitan dalam melakukan aktivitas sehari-hari. Kekakuan otot juga dapat menyebabkan rasa sakit, ankilosis, tendon retraction, atau kelemahan otot pada pasien yang dapat menjadi hambatan potensi keberhasilan rehabilitasi (Thibaut et al,2013).

\subsection{Functional Electrical Stimulator}

Electrical Stimulation merupakan suatu peralatan elektronik yang memberikan rangsangan listrik pada tubuh dengan bentuk gelombang, intensitas, dan frekuensi tertentu. Dalam pemakaiannya, elektrostimulator berfungsi sebagai sumber rangsangan listrik yang mampu menciptakan keseimbangan bioenergi tubuh (Astuti, 2015).

Functional Electrical Stimulation (FES) adalah Electrical Stimulation yang dikendalikan oleh kontroller yang merangsang sistem saraf perifer untuk tujuan memberikan bantuan dinamis dalam kegiatan fungsional, seperti berjalan atau fungsi ekstremitas atas. FES digunakan terutama pada pasien yang mengalami cedera tulang belakang atau menderita stroke untuk mencapai pola gerakan tertentu (Prentice, 2002).

Parameter yang harus diperhatikan dalam perancangan electrical stimulation adalah: frekuensi, frekuensi, lebar pulsa,

amplitude, duty cycle, pola pulsa (Cheng et al, 2004). Pola gelombang Functional Electrical Stimulation berdasarkan bentuknya terbagi menjadi tiga macam: sinus, square dan spike. Ketiga pola
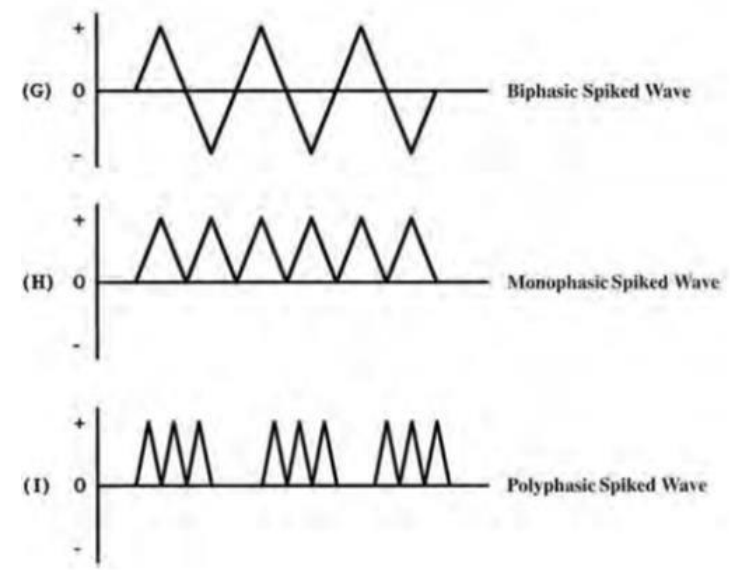

Gambar 2.3. Pola gelombang spike FES

Salah satu faktor penting yang menentukan keberhasilan terapi dengan elektrostimulator adalah ketepatan penentuan dosis energy yang diberikan pada setiap terapi. Jika ditinjau dari bentuk gelombang keluaran spike (Astuti, 2015).

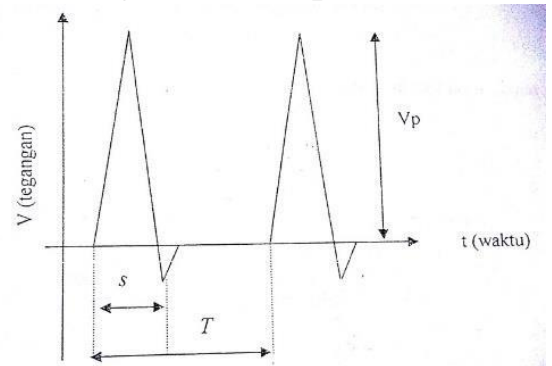

Gambar 2.4. Jenis pulsa spike (astuti, 2015)

Berdasarkan gambar 2.4, dapat dirumuskan bahwa periode pulsa

$$
T=\frac{1}{\ominus}
$$

Persamaan besarnya tegangan keluaran efektif ( $\left.\mathrm{V}_{\text {eff }}\right)$ :

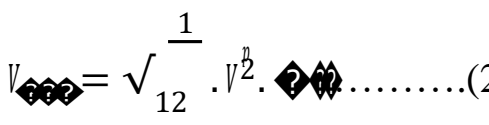

Dimana Vp adalah tegangan puncak (Volt), f adalah frekuensi (Hz) dan s adalah lebar pulsa. Sedangkan daya yang diberikan dapat dihitung berdasarkan persamaan berikut

gel bang tersebut dapat dihasilkan om menjadi monophasic, biphasic dan 
Jurnal Biosains Pascasarjana Vol. 23 (2021) pp

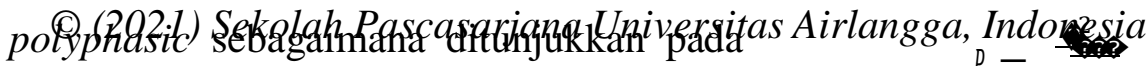

Gambar 2.3 (Prentice, 2002).

Dimana P adalah daya listrik, Veff adalah tegangan efektif (Volt) dan $\mathrm{R}$ adalah resistansi (rata-rata bernilai $500 \mathrm{ohm}$ ). 
(C) (2021) Sekolah Pascasarjana Universitas Airlangga, Indonesia

Sedangkan dosis energi yang masuk ke dalam tubuh dapat dihitung dengan persamaan:

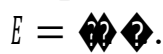

Dimana E adalah dosis energi (Joule) dan t adalah waktu (detik). Sehingga lama waktu terapi dengan dosis energi yang telah ditentukan dapat dihitung dengan menggunakan persamaan:

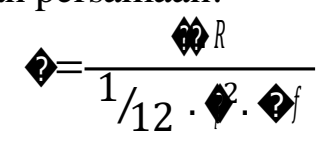

Berdasarkan kajian biofisika, elektrostimulator yang aman dan efektif untuk terapi mempunyai karakteristik (Astuti, 2015) Arus efektif yang dikeluarkan alat maksimum $0,5 \mathrm{~mA}$, Untuk bentuk pulsa spike, tegangan maksimum (Vp) setinggi mungkin, semakin besar Vp rangsangan semakin cepat, dan 3 . Lebar pulsa (s) sekecil mungkin, karena semakin kecil nilai s semakin tidak terasa sakit.

\section{METODE PENELITIAN}

\subsection{Diagram Blok}

Sistem kerja Functional Electrical Stimulation (FES) dimulai dengan pemilihan menu frekuensi dengan menggunakan button switch yang dihubungkan pada mikrokontroler arduino uno. Selanjutnya Arduino akan melakukan aktivasi stimulus berupa gelombang wm dengan lebar pulsa dan frekuensi yang diinginkan. Rangkaian power supply sebagai sumber tegangan. Output Arduino akan berupa pulsa pwm biphasic square dengan lebar pulsa serta frekuensi tertentu namun dengan amplitudo yang relatif kecil yang dihubungkan ke rangkaian penguat. Selanjutnya pulsa output dari Arduino tersebut akan masuk ke rangkaian penguat untuk dikuatkan tegangannya sekaligus untuk merubah pulsa biphasic square menjadi biphasic spike. Rangkaian penguat ini berupa transformator yang dikendalikan transistor daya. Tegangan keluaran transformator ini diharapkan berbentuk pulsa spike, dengan lebar pulsa sangat sempit tetapi tinggi pulsa yang sangat tinggi. Dengan tegangan keluaran transformator berupa pulsa yang sempit dan tajam, kemudian dialirkan ke tubuh pasien menggunakan elektroda sebagai penghubung.

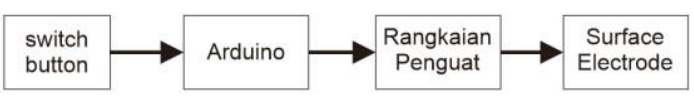

Gambar 3.1 Diagram blok penelitian

\subsection{Desain Rangkaian Penguat}

Rangkaian penguat terdiri dari transistor dan transformator. Untuk memperkuat tegangan amplitudo pulsa keluaran dari Arduino. Selain itu pada rangkaian penguat ini pulsa dari keluaran Arduiono yang berupa pulsa pwm biphasic square akan diubah menjadi pulsa biphasic spike karena adanya ggl induksi. Selain sebagai pelipat tegangan dan pembentuk pulsa spike, transformator sekaligus berfungsi sebagai rangkaian osilasi. Sistem demikian menjamin keamanan terapi, karena tidak ada arus DC sistem elektronik yang mengalir pada pasien.

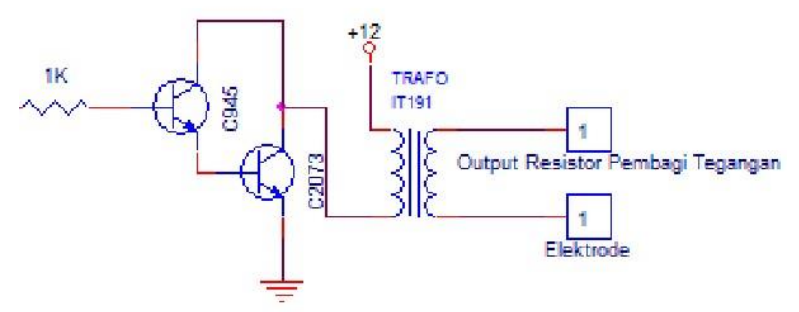

Gambar 3.2 Skema rangkaian penguat

\section{HASIL DAN PEMBAHASAN}

Rangkaian penguat digunakan untuk dapat menaikkan tegangan stimulasi sesuai dengan parameter FES (Functional electrical stimulation), yaitu mendapatkan tegangan puncak Vp tinggi (200 Vp) digunakan transformator OT 240. Resistor digunakan untuk mengecilkan isyarat masukan arus agar tidak membebani rangkaian sebelumnya, kemudian arus dan tegangan outputnya diperkuat dengan penguat darlington yang tersusun dari transistor C945 dan C2703. Dari penguatan tersebut kemudian diteruskan menuju transformator OT 240 yang keluarannya menghasilkan 
(C) (2021) Sekolah Pascasarjana Universitas Airlangga, Indonesia gelombang spike dengan tegangan stimulasi puncak (Vp) antara 0-400 volt.

Arduino berguna untuk mengeluarkan gelombang dengan frekuensi antara $10 \mathrm{~Hz}$ hingga $100 \mathrm{~Hz}$ dengan 10 variasi duty cycle dengan satuan 1 hingga 10 bit, pada resolusi sinyal PWM 8 bit. Adapun hasil pengujian frekuensi keluaran dari frekuensi keluaran Arduino ditunjukkan pada tabel 4.1 dan hasil perhitungan duty cycle ditunjukkan pada tabel 4.2.

Tabel 4.1. Hasil pengujian frekuensi keluaran Arduino

\begin{tabular}{ccc}
\hline \multirow{2}{*}{ Frekuensi } & Frekuensi & $\Delta \mathrm{F}$ \\
& & \\
program $(\mathrm{Hz})$ & Output $(\mathrm{Hz}$ & \\
\hline 10 & 10 & 0.161554944 \\
20 & 19.95 & 0.014282857 \\
30 & 29.96 & 0.030594117 \\
40 & 39.94 & 0.296216137 \\
50 & 50 & 0.040144863 \\
60 & 59.98 & 0.030594117 \\
70 & 69.07 & 0.044271887 \\
80 & 79.95 & 0.397427981 \\
90 & 88.93 & 0.402462421 \\
100 & 100 & 0.717216843 \\
\hline
\end{tabular}

$\Delta \mathrm{F}$ (Standar deviasi dari Frekuensi) yang diperoleh dari Tabel 4.1 sangatlah kecil, hal ini menunjukkan bahwa semakin kecil ketidakpastian pada pengukuran berulang yang telah terlampir, maka semakin besar ketelitian pengukuran tersebut dan program yang dijalankan telah sesuai.

Tabel 4.2. Hasil pengujian perhitungan duty

\begin{tabular}{cc} 
cycle & \\
\hline Bit PWM & Nilai DC $(\%)$ \\
\hline 1 & 0.392156863 \\
2 & 0.784313725 \\
& \\
3 & 1.176470588 \\
4 & 1.568627451 \\
& \\
5 & 1.960784314 \\
6 & 2.352941176 \\
7 & 2.745098039 \\
8 & 3.137254902 \\
9 & 3.529411765 \\
10 & 3.921568627 \\
\hline
\end{tabular}

program maka semakin besar pula presentase PWM yang dihasilkan, semakin besar pula gelombang square yang dihasilkan maka akan bertambah lebar pula bentuk sinyal gelombang spike ketika diamati di osiloskop. Sehingga, dapat disimpulkan bahwa semakin lebar sinyal gelombang square maka semakin tinggi tegangan yang dihasilkan. Perubahan tersebut akan mempengaruhi pada tingkat rasa sakit yang ditimbulkan perangkat terapi dan beresiko bila diterapkan pada pasien.

Pengujian rangkaian penguat dilakukan dengan mengukur tegangan masukan dan tegangan keluaran dari rangkaian dengan menggunakan osiloskop. Besar tegangan keluaran dari penguat Darlington sebelum masuk adalah 12 Volt, dimana pada keadaan ini bentuk gelombang setelah melewati penguat tersebut adalah berbentuk gelombang square, ketika gelombang masukan diteruskan menuiu trafo OT dimana trafo tersehut memiliki sumher langsung sebesar $12 \mathrm{~V}$ yang dihasilkan rangkaian. Hasil penguatan tegangan oleh trafo, pada lilitan input lebih kecil daripada lilitan output sehingga hasil penguatan sinyal gelobang square sebesar $12 \mathrm{~V}$ masuk pada input trafo menjadi $160 \mathrm{~V}$ yang kemudian sinyal gelobangnya berbentuk spike, lalu pada output trafo sinyal gelombang dikuatkan kembali sehingga menjadi 400V. Sinyal gelombang spike yang berbentuk pasak tinggi memiliki lebar pulsa yang kecil yaitu sebesar $0.2 \mathrm{~ms}$.

Tabel 4.3. Hasil Tegangan Puncak (Vpp) dan Arus Keluaran FES pada Frekuensi $100 \mathrm{~Hz}$

$\begin{array}{cccccc}\text { Frekuensi } & \text { Duty } & \text { Vpp } & \text { Veff } & \text { R } & \text { I } \\ \text { Program } & \text { Cycle } & (\mathrm{V}) & (\mathrm{V}) & (\Omega) & (\mathrm{mA})\end{array}$

Berdasarkan Tabel 4.2. dapat disimpulkan bahwa semakin besar nilai duty cycle (bit) yang dimasukkan ke dalam 
Jurnal Biosains Pascasarjana Vol. 23 (2021) pp

(बz)2021)

$\begin{array}{llllll}100 & 0.392 & 60 & 9.693 & 1000 & 0.009\end{array}$

$\begin{array}{llllll}100 & 0.784 & 90 & 1.285 & 1000 & 0.001\end{array}$

$\begin{array}{llllll}100 & 1.176 & 135 & 4.130 & 1000 & 0.004\end{array}$

$\begin{array}{llllll}100 & 1.568 & 155 & 45.913 & 1000 & 0.045\end{array}$

$\begin{array}{llllll}100 & 1.960 & 160 & 6.423 & 1000 & 0.006\end{array}$

$\begin{array}{llllll}100 & 2.352 & 190 & 5.812 & 1000 & 0.005\end{array}$

$\begin{array}{llllll}100 & 2.745 & 295 & 13.060 & 1000 & 0.013 \\ 100 & 3.137 & 300 & 119.228 & 1000 & 0.119 \\ 100 & 3.529 & 400 & 160.984 & 1000 & 0.160 \\ 100 & 3.921 & 400 & 286.886 & 1000 & 0.286\end{array}$


Tegangan puncak, efektif dan arus keluaran perangkat FES pada frekuensi 100 $\mathrm{Hz}$ dengan masing-masing keadaan duty cycle ditunjukkan Tabel 4.3. sedangkan data keseluruhan untuk frekuensi $10-90 \mathrm{~Hz}$ dengan masing-masing keadaan duty cycle terlampir. Pemilihan frekuensi $100 \mathrm{~Hz}$ dengan masing-masing keadaan duty cycle ini dikarenakan pada keadaan tersebut didapatkan variasi tegangan yang mana tegangan puncak yang dapat diamati dengan osiloskop analog yaitu $400 \mathrm{Vp}$. Hal tersebut dikarenakan keterbatasan osiloskop analog dalam menampilkan sebuah sinyal gelombang. Untuk mengetahui besar arus keluaran FES, ditambahkan resistor sebesar $1000 \Omega$ yang dipasang secara seri pada output FES. Sedangkan data perhitungan daya keluaran dari rangkaian FES ditunjukkan pada tabel 4.4 berikut

Tabel 4.4. Hasil Tegangan Puncak (Vpp) dan Arus Keluaran FES pada Frekuensi $100 \mathrm{~Hz}$

\begin{tabular}{|c|c|c|c|c|}
\hline $\begin{array}{l}\text { Frekuensi } \\
\quad(\mathrm{Hz})\end{array}$ & $\begin{array}{l}\text { Duty } \\
\text { Cycle } \\
\text { (bit) }\end{array}$ & $\begin{array}{l}\text { Vpp } \\
(\mathrm{V})\end{array}$ & $\begin{array}{l}\text { Veff } \\
(\mathrm{V})\end{array}$ & $\begin{array}{l}\text { Daya } \\
\text { (Watt) }\end{array}$ \\
\hline 100 & 9 & 400 & 15.198 & 0.230 \\
\hline 90 & 8 & 400 & 14.491 & 0.209 \\
\hline 80 & 7 & 400 & 13.874 & 0.192 \\
\hline 70 & 6 & 400 & 12.845 & 0.164 \\
\hline 60 & 6 & 400 & 12.845 & 0.164 \\
\hline 50 & 5 & 400 & 12.015 & 0.144 \\
\hline 40 & 4 & 400 & 12.015 & 0.144 \\
\hline 30 & 3 & 400 & 12.0154 & 0.144 \\
\hline 20 & 2 & 400 & 12.0154 & 0.144 \\
\hline 10 & 1 & 400 & 12.0154 & 0.144 \\
\hline
\end{tabular}

Berdasarkan referensi uji kinerja FES yang telah dilakukan diketahui bahwa tegangan puncak maksimum ialah $400 \mathrm{~V}$ di setiap variasi keadaan duty cycle terhadap setiap frekuensi. Seharusnya nilai yang didapatkan semakin tinggi frekuensi maka semakin kecil nilai tegangannya. Akan tetapi, pada tabel data diperoleh nilai tegangan efektifnya tidak selalu lebih kecil ketika pada frekuensi yang lebih tinggi, hal ini dikarenakan untuk mendapatkan nilai JBP Vol. 23, No.01, Juni 2021 -Deny Arifianto
Berdasarkan nilai yang didapatkan dari perhitungan daya, diperoleh perhitungan nilai intensitas. Rumus intensitas adalah daya per satuan luas (W/m2). Pada penelitian ini luas elektroda yang berukuran sama pada setiap pengujian yaitu sebesar $3.14 \mathrm{~cm} 2$ atau $0.000314 \mathrm{~m} 2$. Besarnya intesitas keluaran dari FES ditunjukkan pada tabel 4.5 berikut

Tabel 4.5. Hasil pengujian perhitungan duty cycle

\begin{tabular}{cc}
\hline Frekuensi $(\mathrm{Hz})$ & Intensitas $($ Watt $/ \mathrm{m} 2)$ \\
\hline 100 & 735.643 \\
90 & 668.766 \\
80 & 613.036 \\
70 & 525.459 \\
60 & 525.459 \\
50 & 459.777 \\
40 & 459.777 \\
30 & 459.777 \\
20 & 459.777 \\
10 & 459.777 \\
\hline
\end{tabular}

Alat perangkat FES yang telah berhasil dirancang serta telah diuji kinerjanya kemudian diujikan pada pasien pasca stroke, yaitu pasien yang telah sembuh dari penyakit stroke, namun masih menjalani rehabilitasi medis untuk mengembalikan fungsi geraknya. Adapun

tegangan efektif digunakan rumus dengan mengalikan nilai frekuensinya. 
Jurnal Biosains Pascasarjana Vol. 23 (2021) pp

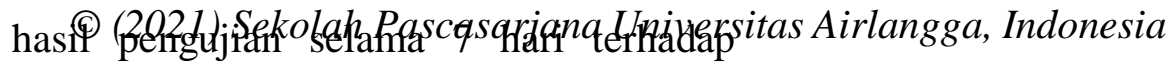
pasien pasca stroke dapat dilihat pada Tabel 4.5. Pengujian dilakukan pada tiga orang pasien pasca stroke dengan nilai MMT 3, MMT 1, dan MMT 0. Seluruh naracoba pasien pasca stroke berusia 50 tahunan.

Pada pemilihan variasi frekuensi dan tegangan stimulus dilakukan secara acak. Naracoba pasien 1 dengan nilai MMT 3 pada hari kesatu hingga hari ketujuh mulai merespon stimulus yang diberikan yaitu ditandai dengan mulai bergeraknya jari-jari tangan pada frekuensi $33 \mathrm{~Hz}$ dengan tegangan sebesar 196 Vpp. Pada hari keempat mengalami kemajuan (nilai ambang tegangan stimulasi untuk dapat memberi respon menurun) yaitu mulai bergeraknya jari-jari tangan pada frekuensi $30 \mathrm{~Hz}$ dengan tegangan sebesar $244 \mathrm{Vpp}$. Naracoba pasien

1 merasakan adanya kemajuan setelah pemberian stimulasi ketika lebih mudah dan 
tidak terlalu merasakan sakit sesaat menggerakkan tangan.

Naracoba pasien 2 dengan nilai MMT 1 mengalami kemajuan hampir di setiap hari pemberian stimulasi. Naracoba pasien 2 pada hari kesatu mulai merespon pada frekuensi $25 \mathrm{~Hz}$ tegangan $387 \mathrm{Vpp}$, hari kedua mulai merespon pada frekuensi $26 \mathrm{~Hz}$ tegangan $336 \mathrm{Vpp}$, hari ketiga dan keempat mulai merespon pada frekuensi 30 $\mathrm{Hz}$ tegangan 244 Vpp. Pasien 2 dapat dikatakan mengalami kemajuan yang lebih signifikan daripada naracoba pasien 1 yang memiliki nilai MMT lebih besar, karena naracoba pasien 2 rutin melakukan terapi serupa yaitu pemberian stimulasi dengan Functional Electrical Stimulation di rumah serta rutin melakukan terapi di Instalasi Rehabilitasi Medik RSUD Dr. Soetomo Surabaya. Naracoba pasien 2 juga merasa lebih mudah untuk menggerakkan tangannya.

Naracoba pasien 3 dengan MMT 0 pada hari kesatu hingga keempat baru mulai merespon pada frekuensi $22 \mathrm{~Hz}$ tegangan 200 Vpp. Naracoba pasien 3 tidak mengalami kemajuan selama pemberian stimulasi. Hal ini dapat disebabkan naracoba pasien 3 memiliki nilai MMT terendah. Selain itu, naracoba pasien 3 baru saja sembuh dari stroke sekitar satu bulan sehingga terapi yang diterima selama proses rehabilitasi juga masih belum terlalu optimal. Ada pun grafik kemajuan respons pasien ditunjukkan pada gambar 4.1 berikut.

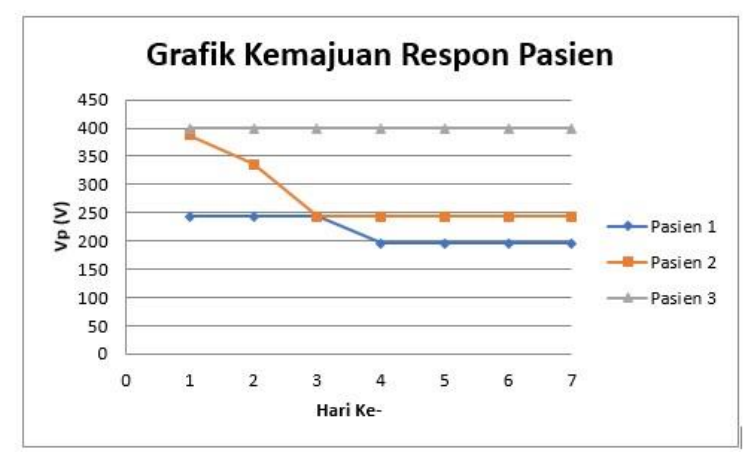

Gambar 4.1. Grafik Kemajuan Respon Pasien Setelah Pemberian Stimulasi

Bentuk gelombang pada penelitian ini adalah spike dengan efektivitas bentuk gelombang didasarkan pada dosis energi yang diberikan. Dosis energi diperoleh dari perkalian antara daya dan waktu. Waktu pemberian stimulus dalam penelitian ini sebesar \pm 2 menit atau 120 sekon. Daya merupakan pembagian dari tegangan efektif kuadrat dengan hambatan rangkaian. Dari hasil pengukuran dan perhitungan, diperoleh nilai tegangan efektif pulsa spike yang sangat kecil. Hal ini menyebabkan gelombang spike lebih terasa nyaman saat mengenai tubuh.

Pada penelitian ini, tegangan efektif maksimal yang dihasilkan adalah $15.19842296 \mathrm{~V}$ dimana tegangan tersebut masuk dalam kategori tegangan rendah. Pemilihan tegangan rendah karena tegangan rendah terasa lebih nyaman daripada tegangan tinggi (Wong, 1986). Semakin tinggi tegangan efektif yang diberikan semakin besar pula energi yang diberikan. Sedangkan arus yang dihasilkan pada penilitian ini adalah $0.015198 \mathrm{~mA}$ yang termasuk dalam kategori arus yang rendah karena dimana $1 \mathrm{~mA}$ adalah batas aman arus yang diperbolehkan masuk ke dalam tubuh (Mayor,2007).

\section{KESIMPULAN}

Telah dibuat Functional electrical stimulation (FES) untuk membantu fungsi ektremitas atas pada penderita pasca stroke dengan lebar pulsa $20 \mu \mathrm{s}$, beberapa variasi frekuensi yaitu $20-50 \mathrm{~Hz}$ dimana tiap frekuensi memiliki beragam variasi tegangan antara 0-400 Vp yang dapat diatur dengan menggunakan potensiometer. Nilai frekuensi berbanding terbalik terhadap nilai tegangan puncak. 10 variasi frekuensi yang diujikan ke naracoba pasien pasca stroke adalah 22 , 23, 24, 25,26, 30, 33, 36, 48, dan $50 \mathrm{~Hz}$. Pemberian stimulasi untuk naracoba pasien dengan nilai MMT 3 mencapai optimal pada frekuensi $22-33 \mathrm{~Hz}$, untuk naracoba pasien dengan MMT 1 mencapai optimal pada frekuensi 22-30 Hz, dan untuk naracoba pasien dengan MMT 1 mencapai optimal pada frekuensi $22 \mathrm{~Hz}$.

Nilai tegangan, frekuensi dan lebar pulsa yang dibutuhkan naracoba pasien 

pasca stroke dengan karakteristik inklusi MMT 0-3 untuk dapat merespon dan menyebabkan gerakan fleksi daerah sekitar pergelangan tangan beragam. Bagi naracoba pasca stroke dengan nilai MMT 0-3 dibutuhkan nilai tegangan, frekuensi dan lebar pulsa minimal sebesar $200 \mathrm{Vp}, 22 \mathrm{~Hz}$, dan $20 \mu$ s dengan daya 0.0014667 Watt.

\section{DAFTAR PUSTAKA}

Adawwiyah, Robi'ah. 2016. Rancang Bangun Functional Electrical Stimulator untuk Membantu Fungsi Ekstremitas Atas Pada Penderita Stroke. Surabaya : Skripsi tidak diterbitkan. Jurusan Teknobiomedik FST UNAIR.

Astuti, Suryani Dyah. 2015. Laporan Program Pengabdian Kepada Masyarakat Pelatihan Komunitas; Pembuatan Desain Peralatan Fisika Medis di SMA Negeri 1 Pacitan. Surabaya : Fakultas Sains dan Teknologi, Universitas Airlangga.

Bourbonnais, Daniel and Sharyn Vanden Noven. 1989. Weakness In Patients With

Cheng, Eric, Yan Lu, Kai-Yu Tong, A. B. Rad, Daniel H. K. Chow, dan Danny. 2004. Development of a Circuit for Functional Electrical Stimulation. IEEE Transactions On Neural Systems And Rehabilitation Engineering.Vol 12, No. 1. 43 - 47.

Conable, Katharine $\mathrm{M}$ and Anthony L. Rosner. 2011. A Narrative Review Of Manual Muscle Testing And Implications For Muscle Testing Research. Journal of Chiropractic Medicine 10, 157-165.

Floyd, R.J. 2007. Manual Of Structural Kinesiology, (17th Ed). WCB McGraw- Hill.

Guyton dan Hall. 2006. Text Book of Medical Phisiology 11th Ed. Chicago: Elsevier Saunders.

Hutomo AP, Buditomo IP, Putra AP, Suhariningsih and Astuti SD, 2019. Design of Monophasic Spike-Exponential Waveform for Functional Electrical Stimulator Based on Pulse Width Modulation, Iranian Journal of Electrical and Electronic Engineering, 15(4):434-443

Hutomo AP, Suhariningsih, Astuti SD, 2018, Rancang Bangun Sistem Pengendali Tegangan Stimulasi Elektrostimulator Otomatis Berbasis Resistansi Tubuh, Jurnal Biosains Pascasarjana vol 20: 146-162

Lum, Peter S, Lum, Sara Mulroy, Richard L. Amdur, Philip Requejo, Boris I. Prilutsky, dan Alexander W. Dromerick. 2009. Gains in Upper Extremity Function After Stroke via Recovery or Compensation: Potential Differential Effects on Amount of Real-World Limb Use. Top Stroke Rehabil;16(4):237-253. Thomas Land Publishers, Inc

Mayor.D.F. 2007. Electroacupuncture : A Practical Manual and Resourse. Livingstone Elsevier. Churchill. National Institute of Neurological Disorder and Stroke. 2014. Brain basics; preventing stroke. Diakses dari www.ninds.nih.gov/disorder/stroke/preventi ng_stroke.htm pada tanggal 25 November 2016.

Prentice, William E. 2002. Theraupetic Modalities for Physical Therapist Second Edition. United States of America: McGraw-Hill Company

Thibaut, Aurore, Camille Chatelle, Erik Ziegler, Marie-Aurelie Burno, Steven Laureys dan Olivia Gosseries. 2013. Spasticity after stroke: Physiology, assessment and treatment.UK: Informa UK Ltd. 1-13

WHO. 2012. The top 10 causes of death diakses dari www.who.int pada tanggal 10 Desember 2016

Wiwit, S. 2010. Stroke dan Penanganannya; memahami, mencegah, dan mengobati. Yogyakarta : Katalog dalam Terbitan, KATAHATI. 